\title{
Relationship of Bradykinin B2 Receptor Gene C-58T Variation with Total-Cholesterol and Glucose in Essential Hypertension
}

Belgin SÜSLEYICI'1, Meliha KOLDEMIR GÜNDÜZ1', Seniyye Ülgen ZENGIN² , Penbe ÇAĞATAY’,

Hasan Mert BOZKUŞ ${ }^{1}$, Nur BAKIR ${ }^{1}$, Mustafa TAŞKIN ${ }^{4}$

${ }^{1}$ Department of Molecular Biology, Marmara University School of Medicine, İstanbul, Turkey

${ }^{2}$ Department of Anesthesiology, Bezmialem Universitesi School of Medicine, İstanbul, Turkey

${ }^{3}$ Division of Biostatistics and Medical Informatics, İstanbul University İstanbul School of Medicine, İstanbul, Turkey

${ }^{4}$ Department of General Surgery, İstanbul University Cerrahpaşa School of Medicine, İstanbul, Turkey

\section{ABSTRACT}

Objective: Hypertension, which affects $25 \%$ of the world's population, is a complex disease, with $30 \%$ genes affecting its pathogenesis. In this study, we aimed to examine the frequency of the bradykinin $\mathrm{B}_{2}$ receptor gene $\mathrm{C}-58 \mathrm{~T}$ genotypes in patients with essential hypertension and non-hypertensive controls. In addition, we evaluated the effects of C-58T genotypes on demographic characteristics, phenotypes related to obesity, and hypertension.

Methods: Genotyping was performed in 63 hypertensive patients and 56 non-hypertensive subjects by PCR-RFLP.

Results: The frequency of bradykinin $\mathrm{B}_{2}$ receptor gene C-58T genotypes in hypertensive patients and control subjects was $25.4 \%$ and $28.6 \%$ for homozygous wild-type (T/T), $49.2 \%$ and $58.9 \%$ for heterozygous (T/C), and $25.4 \%$ and $12.5 \%$ for homozygous polymorphic (C/C) genotypes, respectively. Genotype frequencies did not differ significantly among study groups. The $\mathrm{C}$ allele was found to have an increasing effect on blood glucose levels $(\mathrm{p}=0.05)$ and decreasing effect on total cholesterol levels $(\mathrm{p}=0.008)$ in hypertensive patients, whereas it was found to have an increasing effect on waist circumference $(\mathrm{p}=0.041)$ in control subjects. Hypertensive patients with $\mathrm{C}$ allele were found to use sulfonylurea drugs $(\mathrm{p}=0.021)$ at a higher frequency than those with $\mathrm{T}$ allele. Further, hypertensive patients with $\mathrm{T}$ allele were found to use diuretic drugs $(\mathrm{p}=0.007)$ at a higher frequency than those with $\mathrm{C}$ allele.

Conclusions: The C-58T polymorphism is found to have a positive association with total cholesterol levels, blood glucose levels, and waist circumference but no association with systolic/diastolic blood pressure.

Keywords: Bradykinin, hypertension, cholesterol, waist circumference, blood glucose

\section{Introduction}

Hypertension is a multigenic disease (1). The molecular mechanisms leading to hypertension have largely been clarified.

Bradykinin (BK) is a vasoactive substance that is produced in the blood and in all the tissues due to the effects of kallikreins, which does not exist in the peptide structure. Kinins have functions such as the provision of cardiovascular balance and the formation of an inflammatory response (2). BK, kallidin, and methionyl-lysyl-bradykinin are the members of the kinin family. Kallidin and methionyl-lysyl-bradykinin are transformed into BK by the aminopeptidase enzyme (3). Kinins generally act as regional hormones that act by activating specialized receptors (B1R, B2R) known as B1 and B2. Many inflammatory and cardiovascular effects occur by means of B2 receptors (4, 5). BK is a kinin-kallikrein system member involved in the regulation of blood pressure (6). BK affects the blood pressure by increasing water and sodium discharge with vasodilatation $(7,8)$. BK is involved in insulin-stimulated glucose uptake (9-15). Further, studies have shown that BK has an increasing effect on the insulin sensitivity of the skeletal muscle cells (16-20). In some other studies, the presence of exogenous BK was found to be ineffective on glucose transport in insulin-stimulated 
muscles (21). In the literature, no significant effect of B2R on glycemia has been reported (22).

The water discharge in the body is controlled by the renal BK system via sodium accumulation. The disorder in this mechanism causes vasoconstriction in erythrocytes and vascular smooth muscles. The hypothesis that the renal BK system has an important role in the occurrence of hypertension can be established on the basis of this data (3). By causing the release of prostaglandins and nitric oxide (NO), the passage of $\mathrm{BK}$ into the renal arteries increases the blood flow to the kidneys and causes diuresis and natriuresis $(23,24)$. The production rate or metabolism of BK may change the pathophysiology of hypertension. Under normal circumstances, while BK decreases the blood pressure (3), BK antagonists were found to increase the blood pressure in hypertensive and non-hypertensive rats $(25,26)$. Decreased BK system activity has been found to be associated with many hypertensive events such as sodium accumulation, arterial vasoconstriction, and increase in peripheral resistance (3). BK significantly increases the myocardial blood flow, accelerates cardiac metabolism, and mediates the development of myocardial capillary networks. Kinins have a protective effect on the myocardium with B2R activation $(27,28)$. In addition, BK protects the endothelial cells against aging by inhibiting oxidative stress (29). In summary, BK shows a protective effect against hypertension via B2R activation (30).

The stimulation of $\mathrm{B} 2 \mathrm{R}$ causes severe vasodilatation and an increase in blood flow and hypertension (2). BK B2R shows high affinity toward intact kinins (2). It has been reported that B1R mediates the inflammatory responses produced against kinins and has a contractile effect in the smooth muscles of organs under pathological conditions (2). The angiotensin-converting enzyme (ACE) converts angiotensin 1 to angiotensin 2 and reduces BK (31). However, ACE has been found to show a higher affinity with BK than angiotensin 1 (32) and, hence, the inhibition of ACE leads to a significant increase in $\mathrm{BK}$ concentration (33).

In humans, the structure of the B2R gene of BK has been identified (34-37). Braun et al. (38) have shown that the $\mathrm{B} 2 \mathrm{R}$ gene consists of three exons and two intron regions $(38-40)$. While the first two exon regions are not encoded, the third exon includes the entire gene. The third exon region of the $\mathrm{B} 2 \mathrm{R}$ gene of $\mathrm{BK}$ encodes a protein consisting of 7 transmembrane regions and 364 amino acids (38-40). Although some studies have reported that the promoter polymorphism of BK B2R gene is associated with hypertension (41), some other studies could not demonstrate this association (41). The absence of a direct relationship between the B2R gene polymorphism and hypertension can result from genetic heterogeneity among different races (1). According to meta-analysis studies, while $-58 \mathrm{~T}$ alleles have protective effects in African Americans and Asians, it has a risk factor for hypertension in Europeans (1). Fu et morphism has a synergistic effect with the left ventricular hypertrophy ADE D allele.

The purpose of our study is to determine the gene frequencies of C-58T polymorphism of the BK B2R gene in hypertensive Turkish patients and to determine the relationship of the C$58 \mathrm{~T}$ genotypes (homozygous wild-type $(\mathrm{T} / \mathrm{T})$, heterozygous $(\mathrm{T} / \mathrm{C})$, and homozygous polymorphic $(\mathrm{C} / \mathrm{C})$ ) with blood lipids, obesity-associated phenotypes (fat mass, body mass index (BMI), waist circumference, etc.), and hypertension. The planned study that was applied in the Turkish society for the first time and was evaluated in terms of pharmacogenomics adds new information to the literature.

\section{Methods}

\section{Study Group}

We performed our study with 63 hypertensive (systolic blood pressure (SBP) $\geq 130 \mathrm{mmHg}$ or diastolic blood pressure (DBP) $\geq 90 \mathrm{mmHg}$ ) and 56 non-hypertensive control subjects with normal blood pressure. Conventional risk factors such as dyslipidemia (high-density lipoprotein cholesterol (HDL-chol) values $<40 \mathrm{mg} / \mathrm{dL}$ in men, $<50 \mathrm{mg} / \mathrm{dL}$ in women; triglyceride values $>150 \mathrm{mg} / \mathrm{dL}$; and low-density lipoprotein cholesterol (LDL-chol) levels $>130 \mathrm{mg} / \mathrm{dL}$ ), hypercholesterolemia (total cholesterol (T-chol) levels $>200 \mathrm{mg} \mathrm{dL}$ and LDL-chol levels $>130 \mathrm{mg} / \mathrm{dL}$ or antilipemic agents), hypertension (blood pressure $>130 / 85$ or previously treated), diabetes mellitus (fasting blood glucose $>100 \mathrm{mg} / \mathrm{dL}$ or previously treated), obesity (BMI>25), and smoking (daily smokers) were obtained from the patient records and by asking the patients. Blood pressure was measured using a standard blood pressure monitor in patients at the sitting position from the upper side of the right arms. All the disease diagnoses were made by a specialist cardiologist. For the evaluation of the arterial blood pressure, the guide "The Seventh Report of the Joint National Committee on Prevention, Detection, Evaluation and Treatment of High Blood Pressure Guidelines" (42) was used. Patients having metabolic syndrome corresponded to all the criteria set by the Adult Treatment Panel (ATP III) (43). This work was carried out in accordance with the principles of the Declaration of Helsinki, 2008. Written consent as approved by the local ethics committee was taken from each patient after providing due explanations. Patients with secondary hypertension, diabetic nephropathy, endocrinopathic hypertension, pseudohypertension, neoplasia, and those using oral contraceptives and drugs were not included in the study.

\section{DNA isolation and genotyping}

Genomic DNA was isolated using the standard "saltingout" method (29). The isolated DNAs were purified using the phenol-chloroform method and stored at $-20{ }^{\circ} \mathrm{C}$ until used. The C-58T polymorphism of the BK B2R gene was identified using polymerase chain reaction-restriction fragment length polymorphism (PCR-RFLP). The B2R gene is characterized by the conversion of the thymine nucleotide to cytosine nucleotide at the -58 position in the gene promoter 
region (40). Since the C-58T polymorphism did not lead to a change in the identification sequence for the Mae III enzyme, an identification region for Mae III was generated in the study by adding an incompatible nucleotide to the primer that was meaningful for PCR amplification. The settlement of Mae III was completed in the presence of the $-58^{\circ} \mathrm{C}$ allele. PCR primers were determined as to convert complementary B2R C-58T polymorphism to the promoter/exon 1 area.". The PCR reaction mixture was prepared as a total volume of $25 \mu$ l by taking 30-50 ng of genomic DNA, 0.2 U Taq polymerase (Fermentas), $0.5 \mu \mathrm{l}$ of $100 \mathrm{~mol} / \mathrm{l} \mathrm{dNTP}$, and $0.15 \mu \mathrm{l}$ of $50 \mu \mathrm{mol} / \mathrm{l}$ primer. The PCR cycle conditions were as follows: $7 \mathrm{~min}$ at $95^{\circ} \mathrm{C} ; 35 \mathrm{~min}\left(20 \mathrm{~s}\right.$ at $94^{\circ} \mathrm{C}, 20 \mathrm{~s}$ at $55^{\circ} \mathrm{C}$, and $20 \mathrm{~s}$ at $72^{\circ} \mathrm{C}$ ) at $72^{\circ} \mathrm{C}(44)$. The PCR products were kept at $37^{\circ} \mathrm{C}$ for $4 \mathrm{~h}$, and the cut-off was performed. The primer sequence for the C-58T genotypes was "left primer, 5'-GCCCAGGAGGCTGATGACGTCA-3" and "right primer, 5'-TCACCAACCCTCCGGACCC-3'.” The PCR products were kept overnight at 5 U Mae III (Fermentas) cut-off enzyme. The PCR products produced as $110 \mathrm{bp}$ were divided into $92 \mathrm{bp}$ and $18 \mathrm{bp}$ fragments after the cut-off with the Mae III enzyme. The sodium dodecyl sulfate-polyacrylamide gel electrophoresis (SDS-PAGE) method was used to examine the cut-off products.

\section{Statistical analysis}

The Statistical Package for the Social Sciences 17.0 (SPSS Inc.; Chicago, IL, USA) software program was used for performing statistical analyses. The data were given as mean \pm standard deviation. The comparisons of the patient and control groups with the analyzed parameters were performed through the "Student's t-test." The chi-square $\left(\chi^{2}\right)$ test was used to determine the differences in ratios: in cases where the number of samples in the variables of the category was low, the "Fisher's exact test" was used. In order to investigate the effects of C$58 \mathrm{~T}$ genotypes of the BK B2R gene on the analyzed phenotypes, the analysis of variables among the $\mathrm{T} / \mathrm{T}, \mathrm{C} / \mathrm{T}$, and $\mathrm{C} / \mathrm{C}$ genotypes were performed by the Student's t-test. Data with $p<0.05$ were considered statistically significant. Binary genotype comparisons of the phenotypes found significant were made using the "Mann-Whitney U test." The significance limit for the "Bonferroni analysis" was determined as $\mathrm{p}=0.016$.

\section{Results}

In the hypertensive and non-hypertensive groups, the genotype frequencies of the C-58T polymorphism of the BK $\mathrm{B} 2 \mathrm{R}$ gene are listed in Table 1 . The genotype frequencies of the C-58T polymorphism of the BK B2R gene were found for the $\mathrm{T} / \mathrm{T}, \mathrm{T} / \mathrm{C}$, and $\mathrm{C} / \mathrm{C}$ as $25.4 \%, 49.2 \%$, and $25.4 \%$ in hypertensive patients and $28.6 \%, 58.9 \%$, and $12.5 \%$ in non-hypertensive patients, respectively. Genotype frequencies for the C-58T polymorphism were not found to be statistically significant among the study groups $\left(\chi^{2}=3.183\right.$, $\mathrm{p}=0.204)$ (Table 1).
The effects of the study groups on anthropometric and obesity/ type-2-diabetes/hypertension-related parameters are given in Table 2 . The values of weight ( $\mathrm{p}=0.007)$, fat mass $(0.002)$, BMI $(\mathrm{p}=0.0001)$, blood glucose level $(\mathrm{p}=0.05), \mathrm{T}$-chol $(\mathrm{p}=0.007)$, triglyceride $(\mathrm{p}=0.036)$, LDL-chol $(\mathrm{p}=0.029), \mathrm{SBP}(\mathrm{p}=0.0001)$, DBP $(\mathrm{p}=0.0001)$, and waist circumference $(\mathrm{p}=0.0001)$ were found to be significantly higher in the hypertensive group than in the non-hypertensive group (Table 2).

In the hypertensive group, the effect of $\mathrm{BK} \mathrm{B} 2 \mathrm{R}$ gene C58T genotypes on various phenotypes is given in Table 3 . In hypertensive patients with the $\mathrm{T} / \mathrm{T}$ genotype, $\mathrm{T}$-chol values were higher than hypertensive patients with the $\mathrm{C} / \mathrm{C}$ genotype ( $\mathrm{p}=0.008)$; however, an inverse effect was found in blood glucose levels, and the blood glucose values were found to be lower in hypertensive individuals with the T/T genotype than hypertensive individuals with the $\mathrm{C} / \mathrm{C}$ genotype $(\mathrm{p}=0.05)$. In the other parameters analyzed, no significant effect was detected (Table 3). According to the results of binary comparisons of the BK B2R gene C-58T genotypes for T-chol values, which was found to be statistically significant with the analysis of variance (ANOVA), the T-chol values of hypertensive individuals with the $\mathrm{T} / \mathrm{T}$ genotype were found to be higher than those with the T/C genotype $(\mathrm{p}=0.008)$ (Table 3$)$.

In the non-hypertensive group, the effect of BK B2R gene C-58T genotypes on various phenotypes is given in Table 4 . In non-hypertensive individuals with the $\mathrm{C} / \mathrm{C}$ genotype, the waist circumference measurement was higher than non-hypertensive individuals with the $\mathrm{T} / \mathrm{T}$ genotype $(\mathrm{p}=0.041)$. No statistically significant effect was found on the other analyzed biochemical and clinical parameters such as weight, height, fat-free mass, fat mass, BMI, T-chol, triglyceride, HDL-chol, LDL-chol, SBP, DBP, and blood glucose values (Table 4). In the waist circumference measurements in which genotypes were found effective with ANOVA, according to the MannWhitney $U$ test results of the paired comparisons of the BK $\mathrm{B} 2 \mathrm{R}$ gene $\mathrm{C}-58 \mathrm{~T}$ genotypes, the waist circumference measurements of hypertensive individuals with the $\mathrm{T} / \mathrm{T}$ genotype were found to be higher than those with the T/C genotype $(\mathrm{p}=0.005)($ Table 4).

The frequency of drug use in the hypertensive and non-hypertensive study groups is given in Table 5 . The usage frequencies of diuretic $(\mathrm{p}=0.0001)$, angiotensin-converting-enzyme in-

Table 1. Hipertansif ve hipertansif olmayan bireylerde bradikinin $\mathrm{B}_{2} \mathrm{R}$ geni $\mathrm{C}-58 \mathrm{~T}$ polimorfizmi genotip sıklıkları

\begin{tabular}{|c|c|c|c|c|}
\hline & \multicolumn{4}{|c|}{ Bradykinin $\mathrm{B}_{2} \mathrm{R}$ gene $\mathrm{C}-58 \mathrm{~T}$ genotypes } \\
\hline & T/T n (\%) & $\mathrm{T} / \mathrm{C} n(\%)$ & $\mathrm{C} / \mathrm{C} \mathrm{n}(\%)$ & $\mathbf{P}$ \\
\hline Hypertensive & $16(25.4)$ & $31(49.2)$ & $16(25.4)$ & 0.204 \\
\hline Non-hypertensive & $16(28.6)$ & $33(58.9)$ & $7(12.5)$ & \\
\hline \multicolumn{5}{|c|}{$\begin{array}{l}\text { Results are numerically given (\%). Disease frequencies of the study } \\
\text { group were compared by using the chi-square }\left(x^{2}\right) \text { test. n: number of } \\
\text { samples; } x^{2}: 3.183 ; T / T: \text { wild-type genotype; T/C: heterozygote-type } \\
\text { genotype; C/C: polymorphic-type genotype }\end{array}$} \\
\hline
\end{tabular}


Table 2. Comparison of the study groups in terms of anthropometric and obesity/type-2-diabetes/hypertension-related parameters

\begin{tabular}{|c|c|c|c|}
\hline & Hypertensive $(n=63)$ & Non-hypertensive ( $n=56$ ) & $\mathbf{p}$ \\
\hline Weight (kg) & $77.95 \pm 1.69 ; 76(50-120)$ & $70.93 \pm 1.924 ; 69(50-108)$ & $0.0070 * *$ \\
\hline Height (m) & $1.62 \pm 0.01 ; 1.62(1.44-1.87)$ & $1.64 \pm 0.01 ; 1.63(1.50-1.80)$ & 0.2810 \\
\hline FFBM $(k g)$ & $48.86 \pm 0.93 ; 47.371(34.33-69.21)$ & $47.395 \pm 0.920 ; 47.119(34.33-66.63)$ & 0.4780 \\
\hline $\mathrm{FM}(\mathrm{kg})$ & $29.10 \pm 1.15 ; 28.459(14.87-50.79)$ & $23.53 \pm 1.34 ; 21.59(10.18-43.17)$ & $0.0020^{* *}$ \\
\hline BMI $\left(\mathrm{kg} / \mathrm{m}^{2}\right)$ & $29.75 \pm 0.67 ; 29.10(22.02-42.87)$ & $26.36 \pm 0.72 ; 25.10(20.02-38.02)$ & $0.0001 * * *$ \\
\hline Waist circumference $(\mathrm{cm})$ & $98.66 \pm 1.67 ; 100(72-130)$ & $85.86 \pm 2.30 ; 81(67-120)$ & $0.0001^{* * *}$ \\
\hline T-chol (mg/dL) & $205.49 \pm 6.42 ; 201(114-295)$ & $178.95 \pm 7.18 ; 174.06(49.48-307.35)$ & $0.0070 * *$ \\
\hline TG (mg/dL) & $141.62 \pm 9.29 ; 125(53-383)$ & $118.19 \pm 8.25 ; 102.50(67-265.80)$ & $0.0360^{*}$ \\
\hline HDL-chol (mg/dL) & $48.05 \pm 1.74 ; 46.70(24-79.77)$ & $47.39 \pm 2.05 ; 45.50(24-71.13)$ & 0.8130 \\
\hline LDL-chol (mg/dL) & $106.31 \pm 6.81 ; 104.50(23.58-221)$ & $87.36 \pm 10.73 ; 89(27.84-368.43)$ & $0.0290^{*}$ \\
\hline SBP (mmHg) & $151.57 \pm 2.32 ; 150(100-220)$ & $119.26 \pm 1.26 ; 120(100-130)$ & $0.0001 * * *$ \\
\hline $\mathrm{DBP}(\mathrm{mmHg})$ & $88.33 \pm 1.21 ; 90(60-120)$ & $71.38 \pm 0.93 ; 70(60-85)$ & $0.0001 * * *$ \\
\hline Fasting blood glucose (mg/dL) & $144.74 \pm 14.20 ; 110(57.96-381)$ & $110.05 \pm 12.12 ; 82(39.60-297)$ & $0.0500^{*}$ \\
\hline \multicolumn{4}{|c|}{ 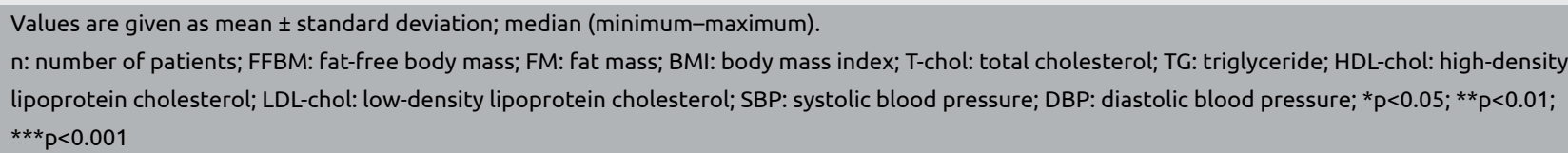 } \\
\hline
\end{tabular}

Table 3. Effect of $\mathrm{BK}_{2} \mathrm{R}$ gene C-58T genotypes on various phenotypes in the hypertensive group

Bradykinin $\mathrm{B}_{2} \mathrm{R}$ gene $\mathrm{C}-58 \mathrm{~T}$ genotypes

\begin{tabular}{|c|c|c|c|c|}
\hline & $T / T(n=16)$ & $T / C(n=31)$ & $C / C(n=16)$ & $\mathbf{p}$ \\
\hline Weight (kg) & $79.40 \pm 3.40 ; 77(62-101)$ & $78.47 \pm 2.04 ; 78(60-99)$ & $75.47 \pm 4.36 ; 72(50-120)$ & 0.688 \\
\hline Height (m) & $1.61 \pm 0.02 ; 1.58(1,50-1,75)$ & $1.62 \pm 0.02 ; 1.59(1.44-1.87)$ & $1.63 \pm 0.20 ; 1.63(1.50-1.78)$ & 0.805 \\
\hline FFBM (kg) & $48.71 \pm 1.64 ; 47.130(40.24-61.01)$ & $48.73 \pm 1.28 ; 47.29(38.62-63.74)$ & $49.24 \pm 2.24 ; 48.09(34.33-69.21)$ & 0.763 \\
\hline $\mathrm{FM}(\mathrm{kg})$ & $30.69 \pm 2.34 ; 29.76(14.87-45.69)$ & $29.74 \pm 1.53 ; 29.13(17.27-48.92)$ & $26.22 \pm 2.47 ; 25.13(15.22-50.79)$ & 0.800 \\
\hline BMI $\left(\mathrm{kg} / \mathrm{m}^{2}\right)$ & $30.65 \pm 1.41 ; 30.04(22.50-42.87)$ & $30.13 \pm 0.96 ; 29.22(22.02-42.29)$ & $28.09 \pm 1.21 ; 27.53(22.22-39.18)$ & 0.348 \\
\hline $\begin{array}{l}\text { Waist } \\
\text { circumference (cm) }\end{array}$ & $99.80 \pm 3.96 ; 99(74-130)$ & $99.70 \pm 2.18 ; 100(76-125)$ & $95.81 \pm 3.17 ; 96(72-120)$ & 0.583 \\
\hline T-chol (mg/dL) & $232.53 \pm 10.97 ; 232.14(146-295)$ & $191.87 \pm 8.54 ; 187$ (124-274) & $199 \pm 13.43 ; 198.50(114-270)$ & $0.008^{*}$ \\
\hline TG (mg/dL) & $157.12 \pm 17.29 ; 127$ (68-298) & $139.85 \pm 14.17 ; 130(55.80-383)$ & $121.60 \pm 13.81 ; 119(53-217)$ & 0.429 \\
\hline HDL-chol (mg/dL) & $52.11 \pm 3.70 ; 50(34-79,77)$ & $45.80 \pm 2.14 ; 45.23(28.40-74)$ & $47.64 \pm 4.05 ; 49(24-65)$ & 0.228 \\
\hline LDL-chol (mg/dL) & $103.63 \pm 14.62 ; 79.50(30.15-221)$ & $99.37 \pm 9.42 ; 101$ (23.58-177) & $127.24 \pm 10.81 ; 124(53-183)$ & 0.960 \\
\hline $\mathrm{SBP}(\mathrm{mmHg})$ & $151.88 \pm 5.26 ; 155(100-180)$ & $154.48 \pm 3.44 ; 150(120-220)$ & $145.63 \pm 3.29 ; 140(120-170)$ & 0.497 \\
\hline $\mathrm{DBP}(\mathrm{mmHg})$ & $90 \pm 3.39 ; 90(60-120)$ & $87.58 \pm 1.55 ; 90(70-110)$ & $88.13 \pm 1.64 ; 90(80-100)$ & 0.181 \\
\hline $\begin{array}{l}\text { Fasting blood } \\
\text { glucose (mg/dL) }\end{array}$ & $110.13 \pm 31.72 ; 79(67.14-298.98)$ & $164.05 \pm 20.99 ; 159(57.96-352)$ & $147.77 \pm 25.01 ; 113(77-381)$ & $0.050^{*}$ \\
\hline \multicolumn{5}{|c|}{$\begin{array}{l}\text { Values are given as meantstandard deviation; median (minimum-maximum). } \\
\text { n: number of patients; FFBM: fat-free body mass; FM: fat mass; BMI: body mass index; T-chol: total cholesterol; TG: triglyceride; HDL-chol: high-density lipoprotein } \\
\text { cholesterol; LDL-chol: low-density lipoprotein cholesterol; SBP: systolic blood pressure; DBP: diastolic blood pressure; T/T: wild-type genotype; T/C: heterozygote- } \\
\text { type genotype; C/C: polymorphic-type genotype } \\
{ }^{*} \mathrm{p}<0.05 ;{ }^{* *} \mathrm{p}<0.01 ;{ }^{* * *} \mathrm{p}<0.001\end{array}$} \\
\hline
\end{tabular}

hibitor ( $\mathrm{p}=0.0001)$, beta blocker $(\mathrm{p}=0.0001)$, acetyl salicylic acid $(\mathrm{p}=0.0001)$, angiotensin II receptor blocker, sulfonylurea nel blocker $(\mathrm{p}=0.004)$, and oral antidiabetic $(\mathrm{p}=0.038)$ were found to be higher in hypertensive individuals than non-hypertensive individuals (Table 5). 
Table 4. The effect of BK B2R gene C-58T genotypes on various phenotypes in the non-hypertensive group

\begin{tabular}{|c|c|c|c|c|}
\hline & \multicolumn{3}{|c|}{ Bradykinin B2R gene C-58T genotypes } & \multirow[b]{2}{*}{$\mathbf{p}$} \\
\hline & $T / T(n=16)$ & $T / C(n=31)$ & $C / C(n=16)$ & \\
\hline Weight (kg) & $71 \pm 3.24 ; 70(53-95)$ & $69.19 \pm 2.39 ; 66.50(50-95)$ & $80.80 \pm 7.61 ; 76(64-108)$ & 0.313 \\
\hline Height (m) & $1.64 \pm 0.02 ; 1.67(1.50-1.78)$ & $1.64 \pm 0.02 ; 1,61(1.50-1.80)$ & $1.67 \pm 0.03 ; 1.64(1.62-1.79)$ & 0.647 \\
\hline FFBM $(\mathrm{kg})$ & $47.34 \pm 1.13 ; 47.14(40.43-54.81)$ & $46.60 \pm 1.23 ; 44.75(34.33-60.71)$ & $52.18 \pm 3.643 ; 49.405(47.05-66.63)$ & 0.321 \\
\hline $\mathrm{FM}(\mathrm{kg})$ & $23.66 \pm 2.79 ; 19.97(10.18-41.92)$ & $22.59 \pm 1.61 ; 22.04(11.86-43.17)$ & $28.62 \pm 4.58 ; 28.95(15.87-41.37)$ & 0.471 \\
\hline BMI $\left(\mathrm{kg} / \mathrm{m}^{2}\right)$ & $26.56 \pm 1.60 ; 23.67(20.20-36.89)$ & $25.84 \pm 0.86 ; 24.69(20.02-38.02)$ & $28.88 \pm 1.96 ; 28.96(22.94-33.71)$ & 0.319 \\
\hline $\begin{array}{l}\text { Waist } \\
\text { circumference (cm) }\end{array}$ & $85.60 \pm 4.71 ; 72(67-120)$ & $82.61 \pm 2.64 ; 79.50(67-120)$ & $101.67 \pm 5.09 ; 101(85-120)$ & $0.041 *$ \\
\hline T-chol (mg/dL) & $186.46 \pm 10.92 ; 185(115-232.41)$ & $175.58 \pm 10.23 ; 166(49.48-307.35)$ & Insufficient number of samples & 0.858 \\
\hline TG (mg/dL) & $120.94 \pm 16.30 ; 97.46(70-260)$ & $116.68 \pm 9.60 ; 108.06(73-265.80)$ & Insufficient number of samples & 0.409 \\
\hline HDL-chol (mg/dL) & $49.64 \pm 3.77 ; 51.80(34-67)$ & $47.19 \pm 2.96 ; 46(24-71.13)$ & Insufficient number of samples & 0.410 \\
\hline LDL-chol (mg/dL) & $73.47 \pm 12.61 ; 52.19(27.84-139)$ & $89.43 \pm 17.07 ; 89(30.15-368.43)$ & Insufficient number of samples & 0.183 \\
\hline $\mathrm{SBP}(\mathrm{mmHg})$ & $117.69 \pm 2.87 ; 115(100-130)$ & $119.31 \pm 1.56 ; 120(100-130)$ & $123 \pm 2 ; 12(120-130)$ & 0.497 \\
\hline $\mathrm{DBP}(\mathrm{mmHg})$ & $71.15 \pm 1.97 ; 70(60-80)$ & $70.69 \pm 1.16 ; 70(60-85)$ & $76 \pm 1.87 ; 75(70-80)$ & 0.181 \\
\hline $\begin{array}{l}\text { Fasting blood } \\
\text { glucose (mg/dL) }\end{array}$ & $122.35 \pm 20.99 ; 97.97(54-243)$ & $100.92 \pm 16.42 ; 80(39.60-297)$ & $117 \pm 45 ; 117(72-162)$ & 0.662 \\
\hline $\begin{array}{l}\text { In individuals with the C, } \\
{ }^{*} p<0.05 ;{ }^{* *} p<0.01 ;{ }^{* * *} p\end{array}$ & $\begin{array}{l}\text { : triglyceride; HDL-chol: high-density li } \\
\text { ire; T/T: wild-type genotype; T/C: heterc } \\
\text { genotype, the values of T-chol, TG, HDL } \\
001\end{array}$ & $\begin{array}{l}\text { otein cholesterol; LDL-chol: low-densit } \\
\text { ote-type genotype; C/C: polymorphic-t } \\
\text { l, and LDL-chol are not given because }\end{array}$ & $\begin{array}{l}\text { gprotein cholesterol; SBP: systolic blo } \\
\text { ufficient number of samples. }\end{array}$ & essure, \\
\hline
\end{tabular}

Table 5. Frequencies of drug use in hypertensive and nonhypertensive groups

\begin{tabular}{|c|c|c|c|}
\hline & $\begin{array}{c}\text { Hypertensive } \\
n(\%)\end{array}$ & $\begin{array}{c}\text { Non-hypertensive } \\
\mathrm{n}(\%)\end{array}$ & $\mathbf{p}$ \\
\hline Diuretic & $28(44.4)$ & $4(7.7)$ & $0.0001^{* * *}$ \\
\hline ACEinh. & $19(32.2)$ & $2(3.8)$ & $0.0001^{* * *}$ \\
\hline Nitrite & $10(15.9)$ & $3(5.8)$ & 0.1380 \\
\hline BB & 39 (61.9) & $5(9.6)$ & $0.0001^{* * *}$ \\
\hline ASA & $35(55.6)$ & $4(7.7)$ & $0.0001^{* * *}$ \\
\hline ATRB & $9(14.3)$ & $1(1.9)$ & 0.0220 * \\
\hline Sulphonylurea & $12(19)$ & $3(5.8)$ & 0.0500 * \\
\hline Glinide & $22(34.9)$ & $7(13.5)$ & 0.0100 * \\
\hline Insulin & $12(19)$ & $6(11.5)$ & 0.3120 \\
\hline Thiazolidine & $3(4.8)$ & $1(1.9)$ & 0.6250 \\
\hline Statin & $25(39.7)$ & $7(13.5)$ & $0.0020 * *$ \\
\hline CCB & $9(14.3)$ & $0(0)$ & 0.0040 * \\
\hline OAD & $33(52.4)$ & $17(32.1)$ & 0.0380 * \\
\hline \multicolumn{4}{|c|}{$\begin{array}{l}\text { Results are presented numerically (\%). n: number of patients; ACEinh: } \\
\text { angiotensin-converting-enzyme inhibitor; BB: beta blocker; ASA: } \\
\text { acetyl salicylic acid; ATRB: angiotensin II receptor blocker; OAD: } \\
\text { oral antidiabetic; CCB: calcium channel blocker }{ }^{*} \mathrm{p}<0.05 \text {; }{ }^{* *} \mathrm{p}<0.01 \text {; } \\
{ }^{* * *} \mathrm{p}<0.001\end{array}$} \\
\hline
\end{tabular}

In the hypertensive group, the effects of drug use on the BK $\mathrm{B} 2 \mathrm{R}$ gene $\mathrm{C}-58 \mathrm{~T}$ genotypes are given in Table 6 . The usage frequency of diuretic drugs $(\mathrm{p}=0.007)$ was found to be higher in hypertensive individuals with the T/T genotype as compared to those with the $\mathrm{T} / \mathrm{C}$ or $\mathrm{C} / \mathrm{C}$ genotypes, and the usage frequency of sulfonylurea $(\mathrm{p}=0.021)$ drugs was higher in individuals with the $\mathrm{C} / \mathrm{C}$ genotype than those with the $\mathrm{C} / \mathrm{T}$ or T/C genotypes (Table 6).

In the non-hypertensive group, the effects of drug use on the BK B2R gene C-58T genotypes are given in Table 7. In individuals with the $\mathrm{C} / \mathrm{C}$ genotype, the usage frequency of acetyl salicylic acid ( $p=0.003)$ drugs was found to be higher than those with the T/T or T/C genotypes. There were no significant effects on the other analyzed medicines such as glinide, oral antidiabetic, metformin, insulin, and statin (Table 7).

The association of hypertensive and non-hypertensive study groups with other diseases has been analyzed in Table 8. In the hypertensive group, the frequency of type- 2 diabetes $(\mathrm{p}=0.025)$ and metabolic syndrome $(\mathrm{p}=0.0001)$ was found to be higher than in the non-hypertensive group (Table 8).

In Table 9, the risk factors associated with hypertension have been presented using multiple logistic regression analysis. C$58 \mathrm{~T}$ polymorphism was not found to be an important risk 
Table 6. Comparison of the effects of BK B2R gene C-58T polymorphism genotypes on drug use in the hypertensive group

\begin{tabular}{|l|c|c|c|c|} 
& \multicolumn{4}{c}{ Bradykinin B R gene C-58T genotypes } \\
& T/T $\mathbf{n}(\%)$ & T/C $\mathbf{~ ( \% ) ~}$ & C/C n (\%) & P \\
\hline Diuretic & $12(75)$ & $12(38.7)$ & $4(25)$ & 0.007 * \\
\hline BB & $12(75)$ & $19(61.3)$ & $8(50)$ & 0.206 \\
\hline Nitrite & $4(25)$ & $5(16.1)$ & $1(6.3)$ & 0.370 \\
\hline ASA & $10(62.5)$ & $19(61.3)$ & $6(37.5)$ & 0.216 \\
\hline ATRB & $2(12.5)$ & $4(12.9)$ & $3(18.8)$ & 0.890 \\
\hline Sulphonylurea & $0(0)$ & $6(19.4)$ & $6(37.5)$ & 0.021 * \\
\hline Glinide & $5(31.3)$ & $11(35.5)$ & $6(37.5)$ & 0.855 \\
\hline Metformin & $5(31.3)$ & $8(25.8)$ & $1(6.3)$ & 0.170 \\
Insulin & $3(18.8)$ & $8(25.8)$ & $1(6.3)$ & 0.260 \\
Statin & $8(50)$ & $12(38.7)$ & $5(31.3)$ & 0.371 \\
CCB & $2(12.5)$ & $2(6.5)$ & $5(31.3)$ & 0.067 \\
OAD & $7(43.8)$ & $16(51.6)$ & $10(62.5)$ & 0.380
\end{tabular}

Results are presented numerically (\%). n: number of patients; BB: beta blocker; ASA: acetyl salicylic acid; ATRB: angiotensin II receptor blocker; OAD: oral antidiabetic; CCB: calcium channel blocker; T/T: wild-type genotype; T/C: heterozygote-type genotype; C/C: polymorphic-type genotype ${ }^{*} p<0.05 ;{ }^{* *} p<0.01 ; * * * p<0.001$

Table 7. Comparison of the effects of BK B2R gene C-58T polymorphism genotypes on drug use in the non-hypertensive group

\begin{tabular}{|l|c|c|c|c|}
\multicolumn{5}{c}{ Bradykinin $\mathbf{B} \mathbf{R}$ gene C-58T genotypes } \\
\hline & $\mathbf{T} / \mathbf{T} \mathbf{n}(\%)$ & $\mathbf{T} / \mathbf{C}$ (\%) & $\mathbf{C} / \mathbf{C} \mathbf{n}(\%)$ & $\mathbf{P}$ \\
\hline ASA & $0(0)$ & $1(3.3)$ & $3(50)$ & $0.003^{*}$ \\
\hline Glinide & $2(12.5)$ & $5(16.7)$ & $0(0)$ & 0.85 \\
Metformin & $4(25)$ & $7(23.3)$ & $0(0)$ & 0.50 \\
Insulin & $1(6.3)$ & $3(10)$ & $2(33.3)$ & 0.27 \\
Statin & $1(6.3)$ & $5(16.7)$ & $1(16.7)$ & 0.61 \\
OAD & $6(37.5)$ & $9(30)$ & $2(28.6)$ & 0.91 \\
\hline
\end{tabular}

Results are presented numerically (\%). n: number of patients; ASA: acetyl salicylic acid; OAD: oral antidiabetic; T/T: wild-type genotype; $\mathrm{T} / \mathrm{C}$ : heterozygote-type genotype; C/C: polymorphic-type genotype

Table 8. Relationship of the study group with type-2 diabetes, dyslipidemia, and metabolic syndrome

\begin{tabular}{|l|c|c|c|} 
& \multicolumn{3}{c}{ Non- } \\
& Hypertensive & hypertensive \\
& $\mathbf{n ( \% )}$ & $\mathbf{n ( \% )}$ & p \\
\hline Type 2 diabetes mellitus & $41(66.1)$ & $24(44.4)$ & $0.025^{*}$ \\
\hline Dyslipidemia & $25(40.3)$ & $13(29.5)$ & 0.307 \\
\hline Metabolic syndrome & $42(66.7)$ & $3(6.8)$ & $0.0001^{* *}$ \\
\hline Results are presented numerically (\%). & & \\
\hline n: number of patients; * ${ }^{*}<0.05 ;$ ** $p<0.001$ & & \\
\hline
\end{tabular}

Table 9. Detection of hypertension-related risk factors via multiple logistic regression analysis

\begin{tabular}{|c|c|c|c|c|}
\hline & \multicolumn{4}{|c|}{ All } \\
\hline & B & SH & OR & $\mathbf{P}$ \\
\hline B2R C-58T T/T Genotype & & & & 0.1120 \\
\hline B2R C-58T T/C Genotype & -0.553 & 0.654 & 0.575 & 0.3980 \\
\hline B2R C-58T C/C Genotype & 1.087 & 0.833 & 1.702 & 0.1920 \\
\hline Dyslipidemia & -0.839 & 0.660 & 0.432 & 0.2030 \\
\hline Type 2 Diabetes Mellitus & -1.675 & 0.726 & 0.187 & $0.0210 *$ \\
\hline Metabolic Syndrome & 4.645 & 0.992 & 104.089 & $0.0001 * *$ \\
\hline Obesity & -0.274 & 0.643 & 0.760 & 0.6700 \\
\hline $\begin{array}{l}\text { B2R C-58T T/T: wild-type ger } \\
\text { genotype; B2R C-58T C/C: } p C \\
\text { * } \mathrm{D}<0.05 ; \text { ** } \mathrm{p}<0.001\end{array}$ & , & OT T & $\begin{array}{l}\text { eterozy } \\
\text { pe }\end{array}$ & \\
\hline
\end{tabular}

factor when examined with other risk factors associated with hypertension (Table 9).

\section{Discussion}

According to the results of many epidemiological studies, genetic components mediate the formation of essential hypertension. Experimental studies in recent years have shown that the $\mathrm{B} 2 \mathrm{R}$ gene has a protective role against the development of hypertension and cardiovascular pathology (45-47). In the studies conducted with mice having silenced B2R gene, the presence of the kallikrein-kinin system was confirmed in cardiac hypertrophy and microvascular diseases, but the baseline blood pressure values did not differ in mice whose B2R gene was abolished and in wild-type mice $(48,49)$. The overexpression of the BK B2R gene is associated with the drop in blood pressure in transgenic mice (50). On the other hand, a slight increase in blood pressure was observed in mice who were fed with salt at very high rates and whose B2R gene was abolished $(51,52)$. However, the blood pressure showed a slight increase as compared to normal values in mice whose $\mathrm{B} 2 \mathrm{R}$ gene was abolished. The abolition of the B2R gene may inhibit the development of hypertension in experimental animals (53). In humans, the frequency of salt-sensitive hypertension has been reported to be higher in African Americans than in Caucasians (54). In some studies, the rate of B2R expression was found to be associated with certain renal pathologies in genetically diabetic, 6-month-old mice (52). From the 12th month onwards, the absence of B2R activation leads to the development of many senescence-associated phenotypes such as hair loss, skin atrophy, hunchback, bone erosion, testicular atrophy, and programmed cell death in the testis and colon with the accumulation of lipofuscin in renal proximal tubules and testicular Leydig cells (53).

Mulatero et al. (44) determined the frequencies of the $\mathrm{C} / \mathrm{C}$, $\mathrm{C} / \mathrm{T}$, and $\mathrm{T} / \mathrm{T}$ genotypes as $32.3 \%, 49.1 \%$, and $18.6 \%$, respectively, in hypertensive primary aldosteronism patients (44). Mukae et al. (55) determined the genotype frequencies 
as $28 \%$ and $18 \%$ for the $\mathrm{C} / \mathrm{C}$ genotype, $59 \%$ and $57 \%$ for the $\mathrm{C} / \mathrm{T}$ genotype, and $13 \%$ and $25 \%$ for the $\mathrm{T} / \mathrm{T}$ genotype in hypertensive and non-hypertensive individuals, respectively (55). Mulatero et al. (44) and Mukae et al. (55) have suggested that the B2R gene is a candidate gene in the formation of essential hypertension $(44,55)$. Fu et al. (41) investigated the effect of B2R C-58T polymorphism on essential hypertension by using the study groups of 275 hypertensive and 441 non-hypertensive individuals. They found the genotype frequencies in hypertensive and non-hypertensive study groups as $24 \%$ and $22 \%$ for the $\mathrm{C} / \mathrm{C}$ genotype, $51 \%$ and $52 \%$ for the $\mathrm{C} / \mathrm{T}$ genotype, and $25 \%$ and $26 \%$ for the $\mathrm{T} / \mathrm{T}$ genotype, respectively (41). Fu et al. (41) could not find any significant association between B2R C-58T polymorphism and essential hypertension. In our study, the frequencies of B2R C-58T genotypes in hypertensive and non-hypertensive study groups were found as $25.4 \%$ and $12.5 \%$ for the $\mathrm{C} / \mathrm{C}$ genotype, $49.2 \%$ and $58.9 \%$ for the T/C genotype, and $25.4 \%$ and $28.6 \%$ for the $\mathrm{T} / \mathrm{T}$ genotype, respectively; however, there was no correlation between the $\mathrm{B} 2 \mathrm{R}$ gene C-58T polymorphism and hypertension.

There are conflicting results about the relationship between the B2R gene C-58T polymorphism and essential hypertension (1). It has been reported that Asian and African American populations have the $\mathrm{B} 2 \mathrm{R}$ gene $\mathrm{C}-58 \mathrm{~T}$ risk allele less frequently in comparison to the Caucasian population and, therefore, they have a lower risk of hypertension (1). A positive association between the B2R gene C-58T polymorphism and essential hypertension has been reported in a study conducted on Europeans (1). Although the $-58 \mathrm{~T}$ allele had a protective effect on essential hypertension in Asians and African Americans, no association was found between the $\mathrm{B} 2 \mathrm{R}$ gene C-58T polymorphism and essential hypertension (1). According to a meta-analysis study, no variation of the BK B2R gene was found to be effective on essential hypertension (1). Mukae et al. (55) studied 100 hypertensive and 100 non-hypertensive samples to investigate the effects of the B2R gene C-58T polymorphism on essential hypertension and found that this polymorphism is a candidate gene for the development of essential hypertension in the Japanese population. Fu et al. (41) investigated the effects of $\mathrm{B} 2 \mathrm{R}$ gene $\mathrm{C}-58 \mathrm{~T}$ polymorphism and ACE I/D polymorphism on left ventricular hypertrophy $(\mathrm{LVH})$ in untreated hypertensive individuals and found that this polymorphism was a risk factor for $\mathrm{LVH}$ and it had a synergistic effect with ACE I/D polymorphism. However, this polymorphism was not associated with hypertension in the Japanese population. A multiple logistic regression analysis performed in the current study did not reveal a significant relationship between the $\mathrm{B} 2 \mathrm{R}$ gene $\mathrm{C}-58 \mathrm{~T}$ polymorphism and essential hypertension. The frequency of BK B2R gene - $58 \mathrm{~T}$ allele differs in ethnic origins.

According to the results we obtained, SBP and DBP values that were not found to be statistically significant in the hypertensive group were found to be lower in individuals with the $\mathrm{C} / \mathrm{C}$ genotype than those with the T/T genotype. This can be explained by the fact that the B2R gene has a low transcriptional expression to the C-58T polymorphism. This may confirm the hypothesis that the $-58 \mathrm{C}$ allele has a protective effect against hypertension.

Akuyam et al. (56) showed that while the T-chol concentration was significantly associated with DBP in hypertensive and non-hypertensive subjects, T-chol values were significantly higher in hypertensive subjects than in non-hypertensive subjects. It is well known that the blood pressure increases with the T-chol level (56). In our study, similar to the study of Akuyam et al. (56), the T-chol level $(\mathrm{p}=0.007)$ was found to be highly significant in hypertensive individuals. However, Tchol values $(\mathrm{p}=0.008)$ were found to be lower in hypertensive individuals with the $\mathrm{C} / \mathrm{C}$ allele as compared to the $\mathrm{T} / \mathrm{T}$ allele. In contrast to the individuals with the $\mathrm{T} / \mathrm{T}$ allele, it can be considered that the $\mathrm{C} / \mathrm{C}$ genotype may lower the T-chol levels in the $\mathrm{C} / \mathrm{C}$ genotype individuals with low SBP and DBP.

Cubeddu et al. (57) reported that blood glucose levels were effective on blood pressure control. It has been reported that glucose increases the blood pressure in endothelial dysfunction and the glucose levels above normal values increase cardiovascular mortality. Similar to the results of the study of Cubeddu et al. (57), glucose levels in hypertensive individuals with the $\mathrm{C} / \mathrm{C}$ allele $(\mathrm{p}=0.05)$ were found in our study to be higher than in hypertensive individuals with the T/T allele. This may indicate that the presence of the $\mathrm{T} / \mathrm{T}$ allele has a lowering effect on the blood glucose levels in hypertensive patients.

Mulatero et al. (44) investigated the effect of B2R gene C$58 \mathrm{~T}$ genotypes on BMI in patients with hypertensive primary aldosteronism and found that BMI measurements in individuals with the $\mathrm{T} / \mathrm{T}$ genotype were lower than those with the $\mathrm{T} / \mathrm{C}$ or $\mathrm{C} / \mathrm{C}$ genotypes. In our study, it was determined that the measurements of BMI and waist circumference changed depending on the B2R gene C-58T genotypes, and it was found that individuals with the $\mathrm{C} / \mathrm{C}$ genotype had higher levels of measurement than the individuals with the $T / T$ genotype. In the presence of the $T / T$ genotype in individuals, the decrease in the levels of BMI and waist circumference may indicate that this genotype has a protective effect on obesity.

According to our literature review, no pharmacogenomic studies were found in relation with the B2R gene C-58T genotypes. In our study, the frequency of patients using diuretic group drugs $(\mathrm{p}=0.007)$ among hypertensive individuals with the $\mathrm{T} / \mathrm{T}$ genotype was found to be higher than hypertensive individuals with $\mathrm{T} / \mathrm{C}$ or $\mathrm{C} / \mathrm{C}$ genotypes. This indicates that among the dyslipidemic patients that constitute $40.3 \%$ of the hypertensive group, individuals with the T/T genotype benefit from this drug. Similar to this, among the T2DM patients that constitute $66.10 \%$ of the hypertensive group, those with the $\mathrm{C} / \mathrm{C}$ genotypes benefit from sulfonylurea group drugs at 
a higher rate $(\mathrm{p}=0.021)$ than those with the other genotypes. The usage frequency of salicylic acid $(\mathrm{p}=0.003)$ was found to be higher in non-hypertensive subjects with the $\mathrm{C} / \mathrm{C}$ genotype as compared to subjects with other genotypes.

The study will be continued by increasing the number of individuals in the patient and control groups in order to achieve results with higher statistical reliability.

\section{Conclusion}

In conclusion, it has been determined that the $\mathrm{BK} \mathrm{B} 2 \mathrm{R}$ gene C-58T polymorphism is not effective on hypertension, but it is related with blood glucose, T-chol levels, and waist circumference. However, due to the effect of the $\mathrm{C} / \mathrm{C}$ genotype on raising the blood glucose level, hypertension patients should consider the possibility of being diabetic. It may be considered that hypertensive individuals with the $\mathrm{C} / \mathrm{C}$ genotypes do not benefit adequately from the diuretic group of drugs.

Ethics Committee Approval: Ethics committee approval was received for this study from the ethics committee of Marmara University.

Informed Consent: Written informed consent was obtained from patients who participated in this study.

Author Contributions: Concept - B.S.D., M.K.G., S.Ü.Z., P.C.., H.M.B., N.B., M.T.; Design - B.S.D., M.K.G., S.Ü.Z., P.Ç., H.M.B., N.B., M.T.; Supervision - B.S.D., M.K.G., S.Ü.Z., P.Ç., H.M.B., N.B., M.T.; Funding - B.S.D., M.K.G., H.M.B., N.B.; Materials - B.S.D., M.K.G., M.T.; Data Collection and/or Processing - M.K.G., H.M.B., N.B.; Analysis and/or Interpretation - B.S.D., M.K.G., P.Ç.; Literature Review - B.S.D., M.K.G., H.M.B., N.B.; Writer - B.S.D., M.K.G., H.M.B., N.B.; Critical Review B.S.D., M.K.G., M.T.; Other- P.Ç., S.Ü.Z., M.T.

Conflict of Interest: No conflict of interest was declared by the authors.

Financial Disclosure: The authors declared that this study has received no financial support.

\section{References}

1. Niu W, Qi Y, Gao P, Zhu D. A meta-analysis of the bradykinin B2 receptor gene --58C/T polymorphism with hypertension. Clin Chim Acta 2010; 411: 324-8. [CrossRef]

2. Pesquero JB, Lindsey CJ, Zeh K, Paiva AC, Ganten D, Bader M. Molecular structure and expression of rat bradykinin $\mathrm{B} 2$ receptor gene. Evidence for alternative splicing. J Biol Chem 1994; 269: 26920-5.

3. Sharma JN. Hypertension and the bradykinin system. Curr Hypertens Rep 2009; 11: 178-81. [CrossRef]

4. Regoli D, Rhaleb NE, Drapeau G, Dion S. Kinin receptor subtypes. J Cardiovasc Pharmacol 1990; 6: 30-8. [CrossRef]

5. Burch RM, Kyle DJ. Recent development in the understanding of bradykinin receptors. Life Sci 1992; 50: 829-38. [CrossRef]

6. Regoli D, Barabé J. Pharmacology of bradykinin and related kinins. Pharmacol Rev 1980; 32: 1-46.

7. Mattson DL, Cowley AW. Kinin actions on renal papillary blood flow and sodium excretion. Hypertension 1993; 21: 961-5. [CrossRef]

8. Katori M, Majima M. Role of the renal kallikrein-kinin system in the development of hypertension. Immunopharmacology 1997; 36: 23742. [CrossRef]

9. Beard KM, Lu H, Ho K, Fantus IG. Bradykinin augments insulinstimulated glucose transport in rat adipocytes via endothelial nitric oxide synthase-mediated inhibition of Jun NH2-terminal kinase. Diabetes 2006; 55: 2678-87. [CrossRef]
10. Duka I, Shenouda S, Johns C, Kintsurashvili E, Gavras I, Gavras H. Role of the $\mathrm{B}(2)$ receptor of bradykinin in insulin sensitivity. Hypertension 2001; 38: 1355-60. [CrossRef]

11. Henriksen EJ, Jacob S. Effects of captopril on glucose transport activity in skeletal muscle of obese Zucker rats. Metabolism 1995; 44: 267-72. [CrossRef]

12. Henriksen EJ, Jacob S, Augustin HJ, Dietze GJ. Glucose transport activity in insulin-resistant rat muscle. Effects of angiotensin-converting enzyme inhibitors and bradykinin antagonism. Diabetes 1996; 1: 125-8. [CrossRef]

13. Henriksen EJ, Jacob S, Fogt DL, Dietze GJ. Effect of chronic bradykinin administration on insulin action in an animal model of insulin resistance. Am J Physiol 1998; 275: 40-5.

14. Henriksen EJ, Jacob S, Kinnick TR, Youngblood EB, Schmit MB, Dietze GJ. ACE inhibition and glucose transport in insulinresistant muscle: roles of bradykinin and nitric oxide. Am J Physiol 1999; 277: 332-6.

15. Miyata T, Taguchi T, Uehara M, Isami S, Kishikawa H, Kaneko K, et al. Bradykinin potentiates insulin-stimulated glucose uptake and enhances insulin signal through the bradykinin B2 receptor in dog skeletal muscle and rat L6 myoblasts. Eur J Endocrinol 1998; 138: 344-52. [CrossRef]

16. Blais C JR, Adama A, Massicotte D, Peronnet F. Increase in blood bradykinin concentration after eccentric weight-training exercise in men. J Appl Physiol 1999; 87: 1197-201.

17. Boix F, Roe C, Rosenborg L, Knardahl S. Kinin peptides in human trapezius muscle during sustained isometric contraction and their relation to pain. J Appl Physiol 2005; 98: 534-40. [CrossRef]

18. Langberg H, Bjorn C, Boushel R, Hellsten Y, Kjaer M. Exercise-induced increase in interstitial bradykinin and adenosine concentrations in skeletal muscle and peritendinous tissue in humans. J Physiol 2002; 542: 977-83. [CrossRef]

19. Stebbins CL, Carretero OA, Mindroiu T, Longhurst JC. Bradykinin release from contracting skeletal muscle of the cat. J Appl Physiol 1990; 69: 1225-30.

20. Taguchi T, Kishikawa H, Motoshima H, Sakai K, Nishiyama T, Yoshizato $\mathrm{K}$, et al. Involvement of bradykinin in acute exercise-induced increase of glucose uptake and GLUT-4 translocation in skeletal muscle: studies in normal and diabetic humans and rats. Metabolism 2000; 49: 920-30. [CrossRef]

21. Dumke CL, Kim J, Arias EB, Cartee GD. Role of kallikrein-kininogen system in insulin-stimulated glucose transport after muscle contractions. J Appl Physiol 2002; 92: 657-64. [CrossRef]

22. Schweitzer GG, Castorena CM, Hamada T, Funai K, Arias EB, Cartee GD. The $\mathrm{B} 2$ receptor of bradykinin is not essential for the post-exercise increase in glucose uptake by insulin-stimulated mouse skeletal muscle. Physiol Res 2011; 60: 511-9.

23. McGiff JC, Itskovitz HD, Terragno NA. The actions of bradykinin and eledoisin in the canine isolated kidney: relationships to prostaglandins. Clin Sci Mol Med 1975; 49: 125-31. [CrossRef]

24. D’Orléans-Juste P, de Nucci G, Vane JR. Kinins act on B1 or B2 receptors to release conjointly endothelium-derived relaxing factor and prostacyclin from bovine aortic endothelial cells. Br J Pharmacol 1989; 96: 920-6. [CrossRef]

25. Benetos A, Gavras I, Gavras H. Hypertensive effect of a bradykinin antagonist in normotensive rats. Hypertension 1986; 8: 1089-92. [CrossRef]

26. Waeber B, Aubert JF, Nussberger J, Vavrek R, Stewart JM, Brunner HR. Role of bradykinin on blood pressure regulation of spontaneously hypertensive rats maintained on different sodium intakes. Clin Exp Pharmacol Physiol 1987; 14:659-64. [CrossRef]

27. Yin H, Chao J, Bader M, Chao L. Differential role of kinin B1 and B2 receptors in ischemia-induced apoptosis and ventricular remodeling. Peptides 2007; 28: 1383-9. [CrossRef]

28. Linz W, Wiemer G, Gohlke P, Unger T, Schölkens BA. Contribution of kinins to the cardiovascular actions of angiotensin-converting enzyme inhibitors. Pharmacol Rev 1995; 47: 25-49. 
29. Oeseburg H, Iusuf $D$, van der Harst $P$, van Gilst WH, Henning RH, Roks AJ. Bradykinin protects against oxidative stress-induced endothelial cell senescence. Hypertension 2009; 53: 417-22. [CrossRef]

30. Marketou M, Kintsurashvili E, Papanicolaou KN, Lucero HA, Gavras I, Gavras H. Cardioprotective effects of a selective $\mathrm{B}(2)$ receptor agonist of bradykinin post-acute myocardial infarct. Am J Hypertens 2010; 23: 562-8. [CrossRef]

31. Erdös EG. Angiotensin I converting enzyme and the changes in our concepts through the years. Lewis K. Dahl memorial lecture. Hypertension 1990; 16: 363-70. [CrossRef]

32. Jaspard E, Wei L, Alhenc-Gélas F. Differences in the properties and enzymatic specificities of the two active sites of angiotensin Iconverting enzyme (kininase II). Studies with bradykinin and other natural peptides. J Biol Chem 1993; 268: 9496-503.

33. Campbell DJ, Kladis A, Duncan AM. Effects of converting enzyme inhibitors on angiotensin and bradykinin peptides. Hypertension 1994; 23: 439-49. [CrossRef]

34. Eggerickx D, Raspe E, Bertrand D, Vassart G, Parmentier M. Molecular clonning, functional expression and pharmacological characterization of a human bradykinin B2 receptor gene. Biochem Biophys Res Commun 1992; 187: 1306-13. [CrossRef]

35. Hess JF, Borkowski JA, Young GS, Strader CD, Ransom RW. Cloning and pharmocoligical characterization of a human bradykinin (BK-2) receptor. Biochem Biophys Res Commun 1992; 184: 260-8. [CrossRef]

36. Powell SJ, Slynn G, Thomas C, Hopkins B, Briggs I, Graham A. Human bradykinin B2 receptor: nucleotide sequence analysis and assignment to chromosome 14. Genomics 1993; 15: 435-8. [CrossRef]

37. Ma JX, Wang DZ, Chao L, Chao J. Clonning, sequence analysis and expression of the gene encoding the mouse bradykinin B2 receptor. Gene 1994; 149: 283-8. [CrossRef]

38. Braun A, Kammerer S, Böhme E, Müller B, Roscher AA. Identification of polymorphic sites of the human bradykinin $\mathrm{B} 2$ receptor gene. Biochem Biophys Res Commun 1995; 211: 234-40. [CrossRef]

39. Kammerer S, Braun A, Arnold N, Roscher AA. The human bradykinin $B 2$ receptor gene: full length cDNA, genomic organization and identification of the regulatory region. Biochem Biophys Res Commun 1995; 211; 226-33. [CrossRef]

40. Braun A, Kammerer S, Maier E, Böhme E, Roscher AA. Polymorphism in the gene for the human B2-bradykinin receptor: new tools assesing a genetic risk for bradykinin-associated diseases. Immunopharmocology 1996; 33: 32-5. [CrossRef]

41. Fu Y, Katsuya T, Matsuo A, Yamamoto K, Akasaka H, Takami Y, et al. Relationship of bradykinin B2 receptor gene polymorphism with essential hypertension and left ventricular hypertrophy. Hypertens Res 2004; 27: 933-8. [CrossRef]

42. Chobanian AV, Bakris GL, Black HR, Cushman WC, Green LA, Izzo JL Jr, et al. Seventh report of the Joint National Committee on Prevention, Detection, Evaluation, and Treatment of High Blood Pressure. Hypertension 2003; 42: 1206-52. [CrossRef]

43. Expert Panel on Detection, Evaluation and Treatment of High Blood Cholesterol in Adults. Executive Summary of The Third Report of The
National Cholesterol Education Program (NCEP) Expert Panel on Detection, Evaluation, And Treatment of High Blood Cholesterol In Adults (Adult Treatment Panel III). JAMA 2001; 285: 2486-97. [CrossRef]

44. Mulatero P, Williams TA, Milan A, Paglieri C, Rabbia F, Fallo F, et al. Blood pressure in patients with primary aldosteronism is influenced by bradykinin $\mathrm{B}(2)$ receptor and alpha-adducin gene polymorphisms. J Clin Endocrinol Metab 2002; 87: 3337-43.

45. Cheng CP, Onishi K, Ohte N, Suzuki M, Little WC. Functional effects of endogenous bradykinin in congestive heart failure. J Am Coll Cardiol 1998; 31: 1679-86. [CrossRef]

46. Emanueli C, Madeddu P. Effect of early blockade of bradykinin B2-receptor on the blood pressure phenotype of normotensive and spontaneously hypertensive rats. Pharmacol Res 1997; 35: 522-6. [CrossRef]

47. Kato M, Shiode N, Yamagata T, Matsuura H, Kajiyama G. Coronary Segmental responses to acetylcholine and bradykinin in patients with atherosclerotic risk factors. Am J Cardiol 1997; 80: 751-5. [CrossRef]

48. Maestri R, Milia AF, Salis MB, Graiani G, Lagrasta C, Monica M, et al. Cardiac hypertrophy and microvascular deficit in kinin $\mathrm{B} 2$ receptor knockout mice. Hypertension 2003; 41: 1151-5. [CrossRef]

49. Cervenka L, Maly J, Karasová L, Simová M, Vitko S, Hellerová et al. Angiotensin II-induced hypertension in bradykinin B2 receptor knockout mice. Hypertension 2001; 37: 967-73. [CrossRef]

50. Mancini GB, Henry GC, Macaya C, O’Neill BJ, Pucillo AL, Carere $\mathrm{RG}$, et al. Angiotensin-converting enzyme inhibition with quinapril improves endothelial vasomotor dysfunction in patients with coronary artery disease. The TREND (Trial on Reversing ENdothelial Dysfunction) Study. Circulation 1996; 94: 258-65. [CrossRef]

51. Bodin S, Chollet C, Goncalves-Mendes N, Gardes J, Pean F, Heudes $\mathrm{D}$, et al. Kallikrein protects against microalbuminuria in experimental type I diabetes. Kidney Int 2009; 76: 395-403. [CrossRef]

52. Kakoki M, Takahashi N, Jennette JC, Smithies O. Diabetic nephropathy is markedly enhanced in mice lacking the bradykinin $\mathrm{B} 2$ receptor. Proc Natl Acad Sci U S A 2004; 101: 13302-5. [CrossRef]

53. Kakoki M, Kizer CM, Yi X, Takahashi N, Kim HS, Bagnell CR, et al. Senescence-associated phenotypes in Akita diabetic mice are enhanced by absence of bradykinin B2 receptors. J Clin Invest 2006; 116: 1302-9. [CrossRef]

54. Grim CE, Robinson M. Blood pressure variation in blacks: genetic factors. Semin Nephrol 1996; 16: 83-93.

55. Mukae S, Aoki S, Itoh S, Nishio K, Iwata T, Ueda H, et al. Promoter polymorphism of the beta2 bradykinin receptor gene is associated with essential hypertension. Jpn Circ J 1999; 63: 759-62. [CrossRef]

56. Osuji CU, Omejua EG, Onwubuya EI, Ahaneku GI. Serum lipid profile of newly diagnosed hypertensive patients in nnewi, South-East Nigeria. Int J Hertens 2012; 2012: 710486. [CrossRef]

57. Cubeddu LX, Hoffmann IS. Insulin resistance and upper-normal glucose levels in hypertension: a review. J Hum Hypertens 2002; 1: 52-5. [CrossRef] 